Article

\title{
Silencing Quorum Sensing through Extracts of Melicope lunu-ankenda
}

\section{Li Ying Tan, Wai-Fong Yin and Kok-Gan Chan *}

Division of Genetics and Molecular Biology, Institute of Biological Sciences, Faculty of Science, University of Malaya, 50603 Kuala Lumpur, Malaysia; E-Mails: etaly87@yahoo.com (L.Y.T.); yinwaifong@yahoo.com (W.-F.Y.)

* Author to whom correspondence should be addressed; E-Mail: kokgan@um.edu.my;

Tel.: +603-7967-5162; Fax: +603-7967-4509.

Received: 18 January 2012; in revised form: 14 March 2012 / Accepted: 22 March 2012 /

Published: 29 March 2012

\begin{abstract}
Quorum sensing regulates bacterial virulence determinants, therefore making it an interesting target to attenuate pathogens. In this work, we screened edible, endemic plants in Malaysia for anti-quorum sensing properties. Extracts from Melicope lunu-ankenda (Gaertn.) T. G. Hartley, a Malay garden salad, inhibited response of Chromobacterium violaceum CV026 to $\mathrm{N}$-hexanoylhomoserine lactone, thus interfering with violacein production; reduced bioluminescence expression of E. coli [pSB401], disrupted pyocyanin synthesis, swarming motility and expression of lecA::lux of Pseudomonas aeruginosa PAO1. Although the chemical nature of the anti-QS compounds from M. lunu-ankenda is currently unknown, this study proves that endemic Malaysian plants could serve as leads in the search for anti-quorum sensing compounds.
\end{abstract}

Keywords: anti-quorum sensing; bioluminescence; lecA::lux; Malaysian plants; $\mathrm{N}$-acyl-L-homoserine lactones (AHL); Pseudomonas aeruginosa PAO1; pyocyanin; virulence; swarming motility

\section{Introduction}

Most Gram-negative bacteria use "quorum sensing" (QS) to coordinate their population behaviour including expression of virulence factors through the action of extracellular signal molecules, such as the $\mathrm{N}$-acyl-L-homoserine lactones (AHLs). QS involves coupling of AHLs to a transcriptional activator 
which in turn modulates QS-mediated gene expressions [1,2]. Gram negative and Gram positive bacteria employ different signal molecules, inasmuch that the former use AHLs while the latter use post-translationally processed peptides $[3,4]$.

Pseudomonas aeruginosa is the opportunistic Gram negative bacterium which is a well-studied model for AHL-mediated QS. [5]. P. aeruginosa has two individual but interconnected QS systems, namely las and rhl. Regulation of virulent factors expressed by $P$. aeruginosa is controlled by the las and $r h l[6,7]$ which are arranged in a hierarchical manner such that the las system activates the $r h l$ system [7]. Myriad virulence factors of P. aeruginosa namely pyocyanin, proteases, haemolysins, exotoxin A and exoenzyme S are QS-dependent [8,9].

Emergence of antibiotic-resistant pathogenic bacteria is now a global threat for public health management. Alternative treatment that does not rely on antibiotics and thus may avoid drug-resistance problems is therefore highly desirable. One such anti-infective treatment is anti-QS molecules, which can quench the virulence phenotypes exerted by pathogenic bacteria [10]. Among the few non bacterial-origin antagonists of QS that have been found are catechin (from Combretum albiflorum bark extract), halogenated furanones (from red alga Delisea pulchra), raspberry, basil and vanilla extracts [11-14].

Not much reported work has been done on endemic plants in Malaysia that show anti-QS activity although some Malaysian plants have been tested for anti-cancer, anti-diabetic, anti-oxidant and other various assays, but not anti-QS effects [15-17]. Therefore, in this paper, we examined a Malaysian endemic plant, Melicope lunu-ankenda (Gaertn.) T. G. Hartley, locally known as "Tenggek burung", for its anti-QS properties. Leaves of M. lunu-ankenda are usually eaten raw as 'ulam' (salad) and are traditionally used to revitalize the body as well as to prevent hypertension.

\section{Experimental Section}

\subsection{Plant Materials and Preparation of Extracts}

M. lunu-ankenda was obtained from a local market located in Selangor (Malaysia). A voucher specimen of M. lunu-ankenda was deposited at the University Malaya Herbarium (Voucher Number: 047697). The plant samples were washed twice with sterile distilled water followed by a final rinse with $70 \%(\mathrm{v} / \mathrm{v})$ ethanol. Plant samples were dried in an oven at $45{ }^{\circ} \mathrm{C}$ for 72 hours. The dried plant samples were ground to a fine powder and submerged sequentially in hexane, chloroform and methanol (ratio 1:10 w/v) for 72 hours. The extracts were filtered through Whatman No.1 paper and concentrated under vacuum using a rotary evaporator. Plant extracts of $10 \mathrm{mg} / \mathrm{mL}(\mathrm{w} / \mathrm{v}$ in $100 \%$ DMSO) were diluted with sterile distilled water to $1,2,3,4$ and $5 \mathrm{mg} / \mathrm{mL}$ prior to use.

\subsection{Bacterial Strains, Growth Media and Culture Conditions}

Bacterial strains used in this study are listed in Table 1. Bacteria were grown in Luria-Bertani (LB) medium $(1 \% \mathrm{w} / \mathrm{v} \mathrm{NaCl}, 1 \% \mathrm{w} / \mathrm{v}$ tryptone, $0.5 \% \mathrm{w} / \mathrm{v}$ yeast extract) with shaking $(220 \mathrm{rpm})$. Chromobacterium violaceum CV026 was cultured in $28{ }^{\circ} \mathrm{C}$, while $P$. aeruginosa strains at $37{ }^{\circ} \mathrm{C}$. C. violaceum CV026 growth medium was supplemented with kanamycin $(30 \mu \mathrm{g} / \mathrm{mL})$ and chloramphenicol $(30 \mu \mathrm{g} / \mathrm{mL})$. 
Table 1. Strains Used in This Study.

\begin{tabular}{|c|c|c|}
\hline Strain & Description & Source/Reference \\
\hline $\begin{array}{l}\text { C. violaceum } \\
\text { CV026 }\end{array}$ & 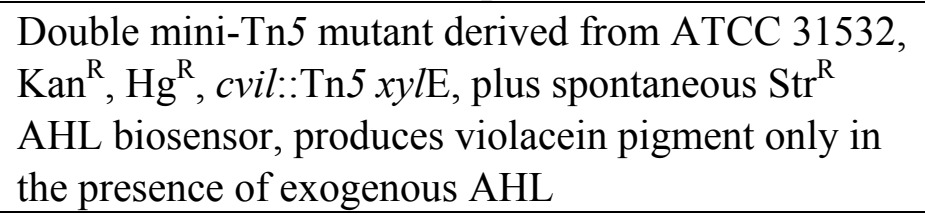 & {$[18]$} \\
\hline $\begin{array}{l}\text { P. aeruginosa } \\
\text { PA01 } \\
\text { lecA::lux }\end{array}$ & $\begin{array}{l}\text { Prototroph } \\
\text { lecA::luxCDABE } \\
\text { genomic reporter fusion in PA01 }\end{array}$ & [19] \\
\hline \multicolumn{3}{|l|}{ Escherichia coli } \\
\hline [pSB401] & $\begin{array}{l}\text { luxRluxl' (Photobacterium fischeri } \\
\text { [ATCC 7744])::luxCDABE (Photorhabdus } \\
\text { luminescens [ATCC 29999]) fusion; pACYC184- } \\
\text { derived, Tet }{ }^{\mathrm{R}} \text {, AHL biosensor producing } \\
\text { bioluminescence }\end{array}$ & [20] \\
\hline [pSB1075] & $\begin{array}{l}\text { lasRlasl'(P. aeruginosa } \mathrm{PAO} 1):: \text { luxCDABE } \\
\text { (Photorhabdus luminescens [ATCC 29999]) fusion in } \\
\text { pUC18 Amp }{ }^{\mathrm{R}} \text {, AHL biosensor producing } \\
\text { bioluminescence }\end{array}$ & {$[20]$} \\
\hline
\end{tabular}

\subsection{C. violaceum CV026 Assay}

C. violaceum CV026 assay was performed as described by Renee and Gray [21] with modification. Overnight grown $C$. violaceum CV026 cells $(15 \mathrm{~mL})$ were added into $200 \mathrm{~mL}$ of molten LB agar that has been supplemented with $N$-hexanoylhomoserine lactone (C6-HSL, $0.25 \mu \mathrm{g} / \mathrm{mL}$ ). C. violaceum CV026 agar suspension was poured into Petri dishes and allowed to solidify, wells were then made using sterile pipette tips. Plant extract $(30 \mu \mathrm{L})$ was placed in each well and the extract solvent (DMSO, $50 \% \mathrm{v} / \mathrm{v}$ ) served as the negative control. The plates were incubated at $28{ }^{\circ} \mathrm{C}$ for 24 hours. Halo formation on a purple background suggested that the plant extracts exhibited anti-QS.

\subsection{Violacein Quantification Assay}

Violacein quantification assay was performed in a 96-well plate [22]. Optical density $\left(\mathrm{OD}_{600 \mathrm{~nm}}\right)$ of overnight culture of $C$. violaceum CV026, supplemented with C6-HSL $(0.125 \mu \mathrm{g} / \mathrm{mL})$, was adjusted to 1.2 prior to use. C. violaceum CV026 cells $(90 \mu \mathrm{L})$ were added to each well followed by the addition of $10 \mu \mathrm{L}$ of plant crude extract. The 96-well plate was incubated at $28{ }^{\circ} \mathrm{C}$ in a shaking incubator. After 16 hours, the mixtures in the 96-well plate were completely dried at $60{ }^{\circ} \mathrm{C}$. DMSO $(100 \mu \mathrm{L})$ was added onto each well and the microplate was placed in a shaker until all the violacein was solubilized. The absorbance of each well was read at $590 \mathrm{~nm}$ using DYNEX MRX Elisa reader (Chantilly, VA, USA). 


\subsection{Quantification of Bioluminescence from E. coli [pSB401] and E. coli [pSB1075]}

Bioluminescence expression was quantified using a Tecan luminometer (Infinite M200, Männerdorf, Switzerland). Briefly, overnight culture of $E$. coli biosensors cells was diluted to an $\mathrm{OD}_{600 \mathrm{~nm}}$ of 0.1 . Then, $230 \mu \mathrm{L}$ of $E$. coli biosensors cells and $20 \mu \mathrm{L}$ of plant extract were added into the well of 96-well microtitre plate. The bioluminescence and $\mathrm{OD}_{495 \mathrm{~nm}}$ were determined every $30 \mathrm{~min}$ for 24 hours by the luminometer [19]. Expression of bioluminescence was given as relative light unit (RLU)/OD $495 \mathrm{~nm}$ against time [19]. Reduction of bioluminescence in E. coli [pSB401] and E. coli [pSB1075] suggested anti-QS properties of the plant extracts.

\subsection{Pyocyanin Quantification Assay}

Pyocyanin quantification assay was performed as described by Essar et al. [23] with slight modification. Briefly, overnight culture of P. aeruginosa PA01 was adjusted to an $\mathrm{OD}_{600 \mathrm{~nm}}$ of 0.2. Then, $250 \mu \mathrm{L}$ of plant extract was added and mixed well with $P$. aeruginosa PA01 cells $(4.75 \mathrm{~mL})$ in a polypropylene tube and incubated at $37{ }^{\circ} \mathrm{C}$ for 24 hours. The $5 \mathrm{~mL}$ culture was extracted with $3 \mathrm{~mL}$ of chloroform, followed by mixing the chloroform layer with $1 \mathrm{~mL}$ of $0.2 \mathrm{M} \mathrm{HCl}$. The absorbance of the pink extracted organic layer was then measured at $520 \mathrm{~nm}$ using the UV-visible spectrophotometer (UV1601, Shidmazu, Kyoto, Japan).

\subsection{Quantification of $\mathrm{P}$. aeruginosa $P A 01$ lecA Expression}

P. aeruginosa PA01 lecA expression was quantified using a Tecan luminometer (Infinite M200). Briefly, overnight culture of $P$. aeruginosa PA01 lecA::lux was diluted to an $\mathrm{OD}_{600 \mathrm{~nm}}$ of 0.1 . Then, $230 \mu \mathrm{L}$ of $P$. aeruginosa PA01 lecA::lux and $20 \mu \mathrm{L}$ of plant extract were added into the well of 96-well microtitre plate. The bioluminescence and $\mathrm{OD}_{495 \mathrm{~nm}}$ were determined every 30 min for 24 hours by the Tecan luminometer. $P$. aeruginosa PA01 lecA::lux expression was given as relative light unit (RLU)/OD $495 \mathrm{~nm}$ against time [19]. Reduction in the bioluminescence of $P$. aeruginosa PA01 lecA::lux suggested anti-QS properties of the plant extracts.

\subsection{P. aeruginosa PA01 Swarming Assay}

Swarming agar was prepared by the following compositions: glucose $(1 \% \mathrm{w} / \mathrm{v})$, Bacto agar $(0.5 \% \mathrm{w} / \mathrm{v})$, Bacto peptone $(0.5 \% \mathrm{w} / \mathrm{v})$ and yeast extract $(0.2 \% \mathrm{w} / \mathrm{v})$. Solidified swarming agar $(10 \mathrm{~mL})$ was overlaid with $4.75 \mathrm{~mL}$ of swarming agar supplemented with $250 \mu \mathrm{L}$ of plant extract. Overnight culture of $P$. aeruginosa PA01 $(2 \mu \mathrm{L})$ was inoculated in the centre of the agar and incubated for 16 hours at $37^{\circ} \mathrm{C}$. Reduced swarming motility of $P$. aeruginosa PA01 suggested anti-QS properties of the plant extracts.

\subsection{Statistical Tests}

All assays were performed on triplicate basis and the significance of the data was tested using ANOVA test $(P<0.05)$ using GraphPad Prism software. 


\section{Results and Discussion}

The purpose of this study was to investigate the anti-QS properties of endemic Malaysian plants, in particular, edible plants. M. lunu-ankenda is a kind of "ulam" that is widely consumed as garden salad by the Malay community in Malaysia and it has shown no adverse effects on human health. It is also traditionally used to treat hypertension. However, not much scientific studies have been carried out on M. lunu-ankenda and there is no reported work that studies the anti-QS properties of M. lunu-ankenda.

\subsection{CV026 Plate Assay}

Formation of a visible halo zone indicates anti-QS action exerted by the plant extract. In Figure 1, a halo zone was formed when the extract was applied at $1 \mathrm{mg} / \mathrm{mL}$ and the size of the halo zone increased in parallel with the concentration of the M. lunu-ankenda hexane extract (Figure 1).

Figure 1. Figure shows each well containing $30 \mu \mathrm{L}$ of $M$. lunu-ankenda extracted with the following solvents: (a) hexane; (b) chloroform; (c) methanol, applied at the concentration of $1,2,3,4$ and $5 \mathrm{mg} / \mathrm{mL}$.

(a)
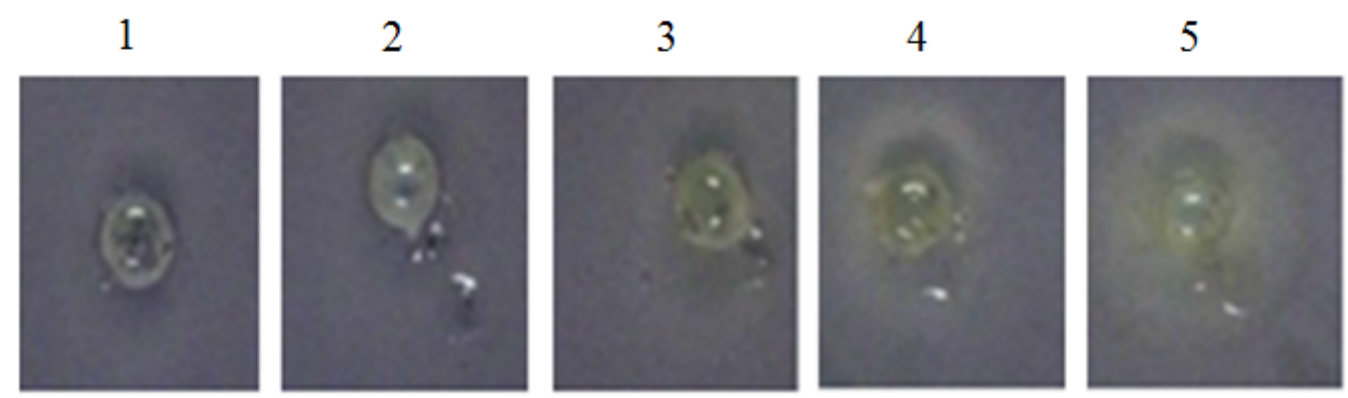

$(\mathrm{mg} / \mathrm{mL})$

(b)
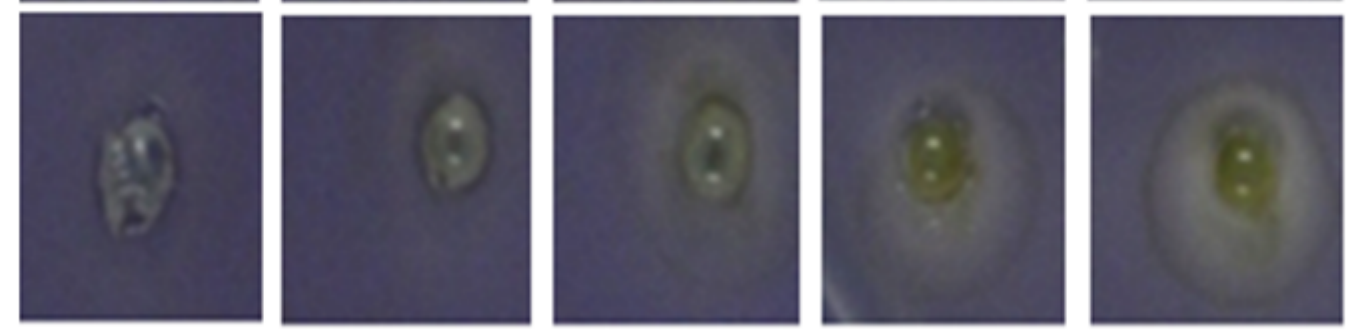

(c)
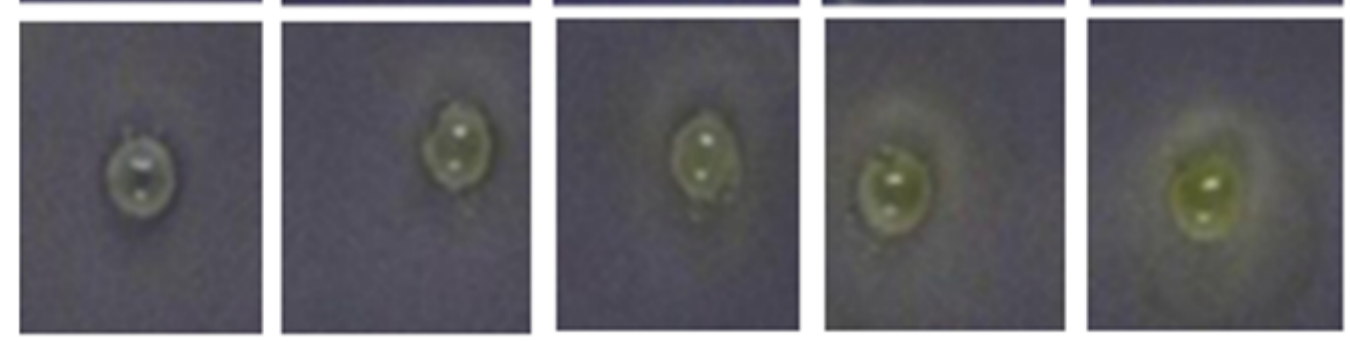

This suggests stronger anti-QS action of the extract corresponds to its increasing concentration. In contrast, M. lunu-ankenda chloroform extract showed weaker anti-QS properties as it only started to exert its anti-QS effect at a concentration of $2 \mathrm{mg} / \mathrm{mL}$ (Figure 1). As compared to the M. lunu-ankenda hexane extract, the methanolic extract showed weaker anti-QS activity (Figure 1). DMSO (50\% v/v) served as the negative control which showed no bactericidal or anti-QS effects (data not shown). 


\subsection{Violacein Quantification Assay}

Anti-QS activity of $M$. lunu-ankenda extracts (applied at 1, 2, 3 and $4 \mathrm{mg} / \mathrm{mL}$ ) were analyzed using violacein quantitative assay and DMSO (10\%, 20\%, 30\% and 40\% v/v) served as the negative controls at each corresponding concentrations. By using the statistical ANOVA test, it was found that M. lunu-ankenda chloroform and methanol extracts of $4 \mathrm{mg} / \mathrm{mL}$ causes significant inhibition of violacein as compared to the control (Figure 2). In general, there was reduction in violacein production as the concentration of the extracts increases. However, these reductions were not significantly different at $P<0.05$.

Figure 2. Inhibition of violacein production by $M$. lunu-ankenda extracted with the following solvents: (a) hexane; (b) chloroform and (c) methanol.

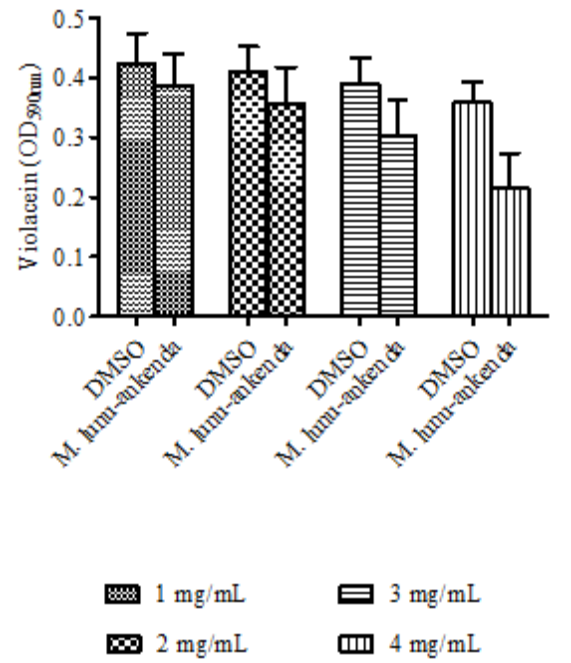

(a)

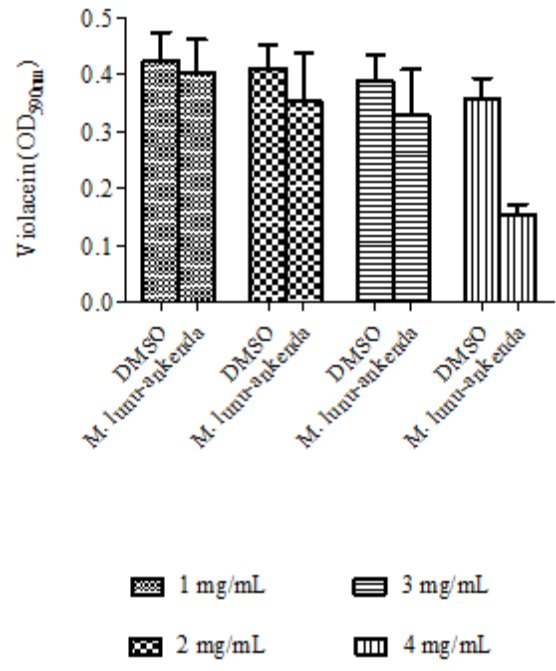

(b)

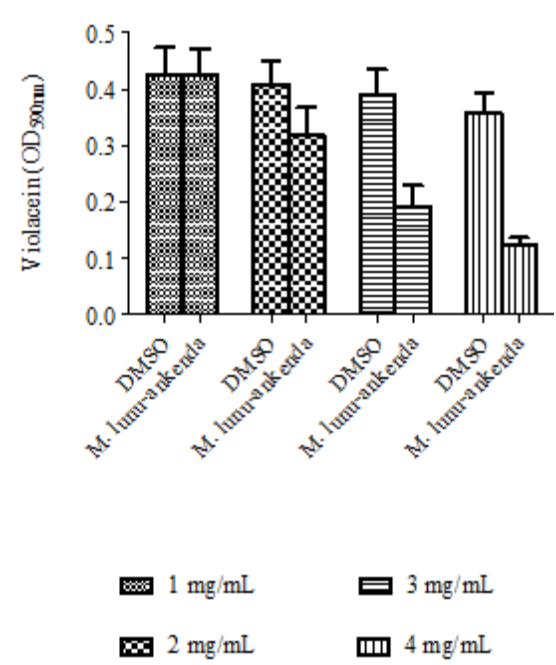

(c)

C. violaceum is a Gram negative bacterium which synthesizes the purple pigment violacein, a QS-mediated trait regulated by C6-HSL. C. violaceum CV026, on the other hand, is a transposon mutant strain of $C$. violaceum that is unable to synthesize C6-HSL. Thus, $C$. violaceum CV026 can only produce violacein in the presence of exogenous short chain AHLs [14,18]. In C. violaceum CV026 plate assay, formation of halo zone indicates the plant samples is either inhibiting the C6-HSL competitively from binding to its transcriptional regulator, cviR; degrading the C6-HSL enzymatically, or removing the C6-HSL via active transport [24-26]. Inhibition on violacein production was quantified and from the results obtained in this study, it was proven that M. lunu-ankenda reduced violacein production significantly. In agreement to this finding, other plant extracts such as vanilla, Tremella fuciformis, Conocarpus erectus, Quercus virgiana, pea seedlings and other various higher plants have been found to possess anti-QS activity against biosensor strain C. violaceum CV026 [10,14,24,27,28]. 


\subsection{Quantification of Bioluminescence from E. coli $p S B$ [401] and E. coli $p S B$ [1075]}

All three solvents extracts of Melicope lunu-ankenda showed significant inhibition against E. coli [pSB401], but not E. coli [pSB1075] (data not shown). E. coli [pSB1075] produces optimum luminescence in the presence of exogenous $\mathrm{N}$-3-dodecanoylhomoserine lactone (3-oxo-C12-HSL) [20]. Plant extracts that reduced bioluminescence of E. coli [pSB401] and E. coli [pSB1075] suggest the presence of anti-QS activity.

\subsection{Pyocyanin Quantification Assay}

Pyocyanin is one of the exoproducts produced by $P$. aeruginosa. It causes extensive cellular damage in the lungs of cystic fibrosis patients. Chloroform and hexane extracts of M. lunu-ankenda showed significant reduction in pyocyanin production (Figure 3(a,b)). The methanolic extract only showed significant reduction of pyocyanin at $3 \mathrm{mg} / \mathrm{mL}$ (Figure $3(\mathrm{c})$ ).

Figure 3. Inhibition of pyocyanin production by $M$. lunu-ankenda extracted with the following solvents: (a) hexane; (b) chloroform and (c) methanol.

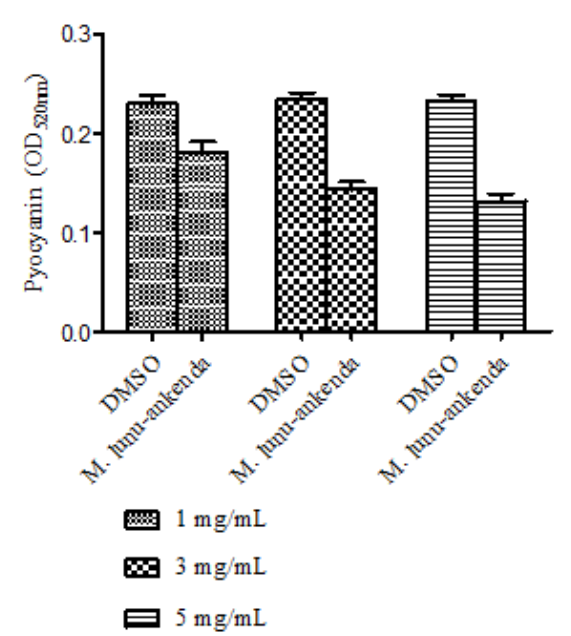

(a)

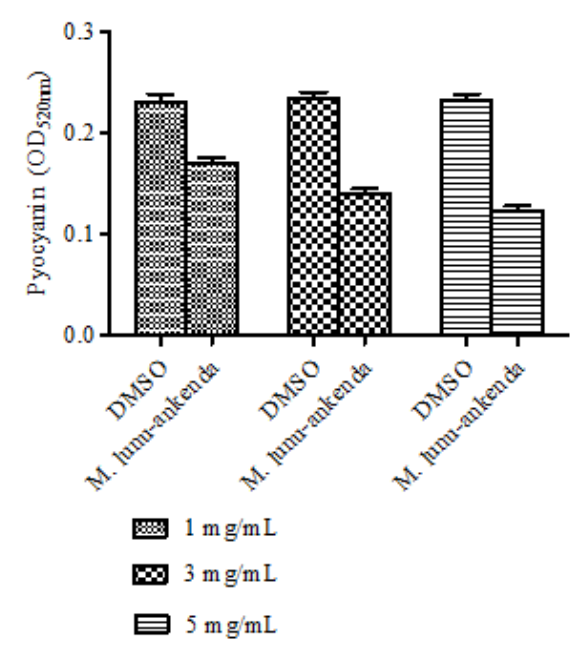

(b)

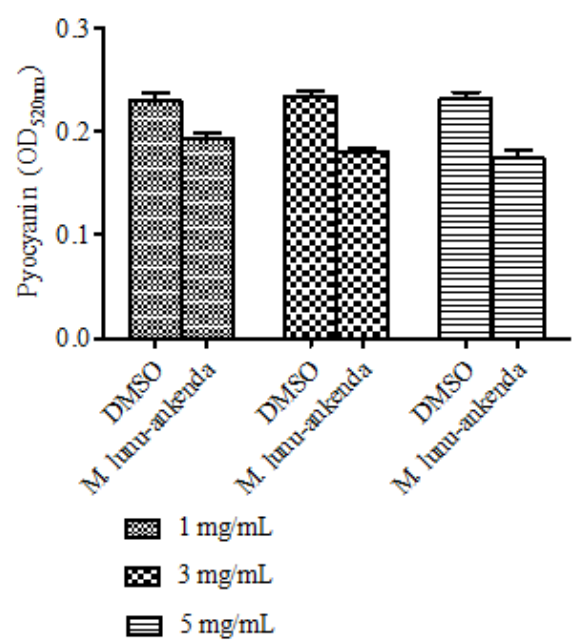

(c)

Pyocyanin can be found in great quantity in the sputum of cystic fibrosis patients and it is also highly permeable to the biological membranes. P. aeruginosa causes developing loss of pulmonary function which leads to premature death in the majority of cystic fibrosis patient [29,30]. Mutations in lasR-lasI, rhlR-rhlI and the mvfR-haq QS systems caused loss in pyocyanin production [31,32]. These QS systems are also involved in production of among others, rhamnolipids, proteases and elastase [30]. Pyocyanin formation involved a multifactorial system and though extracts of M. lunu-ankenda could significantly inhibit its production in this study, it is possible that the compounds from M. lunu-ankenda influence directly the virulence factor production in a QS independent manner. A study found that cyclic disulphides and trisulphides obtained from garlic have no antibiotic properties but instead suppress the expression of LuxR and LuxR based QSI in P. aeruginosa [33,34]. 


\subsection{Quantification of P. aeruginosa PA01 lecA Expression}

P. aeruginosa PA01 lecA::lux was constructed by the cloning of luxCDABE (from Photorhabdus luminescens) into the lecA gene region of $P$. aeruginosa $[19,20]$. The hexane and chloroform extracts of M. lunu-ankenda caused a significant reduction in PA01 lecA expression (Figure 4). However, the methanolic extract did not show any observable results (data not shown). lecA is the structural gene of PA-IL, which is a cytotoxic lectin. Synthesis of lectin is directly related to the $r h l$ locus as it has been demonstrated that in the las $R$ mutant, lectin synthesis was delayed but not prevented totally $[19,35,36]$. Reduction of $P$. aeruginosa PA01 lecA::lux expression by M. lunu-ankenda extracts indicates that these extracts were exerting theirs activity more on the $r h l$ system which also controls the expression of elastase and biofilm. Similarly, rosmarinic acid reduces the expression of proteases, elastases and biofilm in $P$. aeruginosa has been reported [37].

Figure 4. $P$. aeruginosa PA01 lecA expression after treated by M. lunu-ankenda extracted with (a) hexane; (b) chloroform, all applied at $1 \mathrm{mg} / \mathrm{mL}$.

(a)

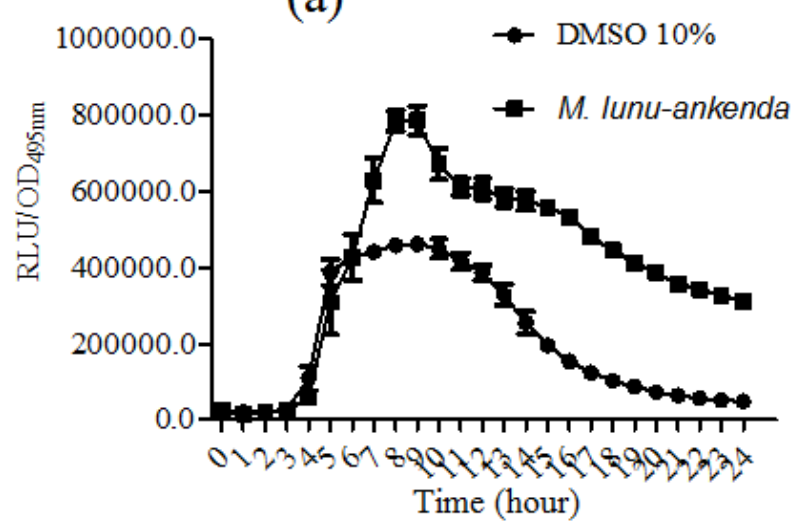

(b)

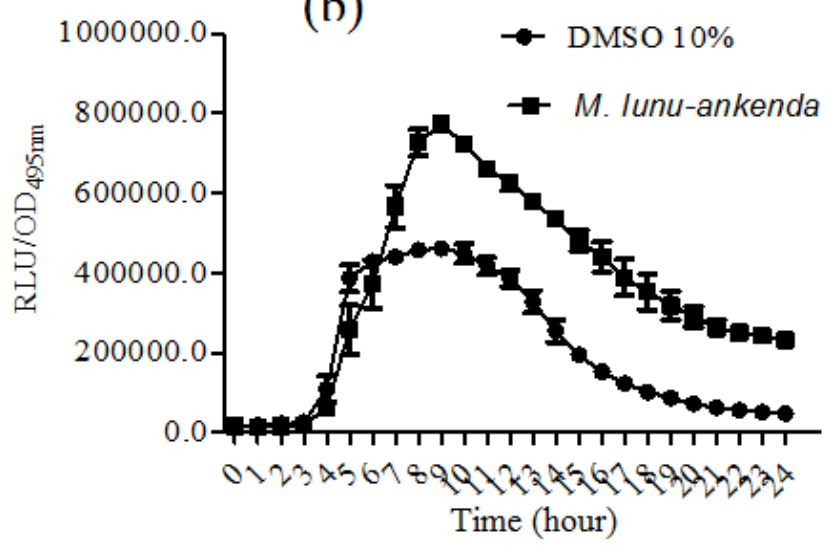

\subsection{Swarming Assay}

Swarming refers to the bacterial surface translocation which is QS-dependent and it requires flagella and pili [38,39]. Of the three extracts of M. lunu-ankenda, only the chloroform extract showed inhibition against the swarming of $P$. aeruginosa. Swarming, swimming, gliding, twitching, sliding and darting are modes of surface translocation used by bacteria [38]. In this study, we investigated the anti-swarming ability of $M$. lunu-ankenda extract against $P$. aeruginosa PAO1. Generally, there are 3 stages in the swarming process, firstly, differentiation of vegetative cells into swarmer cells, followed by migration of swarmer cell populations and finally consolidation [40,41]. The extract of M. lunu-ankenda were seeded into the swarming agar and as shown in Figure 5, the chloroform extract showed observable inhibition against the swarming of $P$. aeruginosa PAO1. The extract of M. lunu-ankenda might be exerting its inhibition of swarming during the migration of swarmer cells or causing biofilm dispersal. Similar observation has also been observed in malabaricone $\mathrm{C}$, a compound purified from nut meg extract [42]. Subsequently, as the migration process is a QS-regulated trait, further studies can be done by using the mutants of PA01 which is deficient in QS. 
Figure 5. Swarming inhibition assays. Swarming agars of (a) P. aeruginosa PAO1 supplemented with (b) DMSO 30\% (v/v, negative control); and M. lunu-ankenda-chloroform extracts of (c) $1 \mathrm{mg} / \mathrm{mL}$ (d) $2 \mathrm{mg} / \mathrm{mL}$ and (e) $3 \mathrm{mg} / \mathrm{mL}$. Images shown are $P$. aeruginosa PAO1 swarming patterns and inhibition effects after 16 hours of incubation in $37^{\circ} \mathrm{C}$.

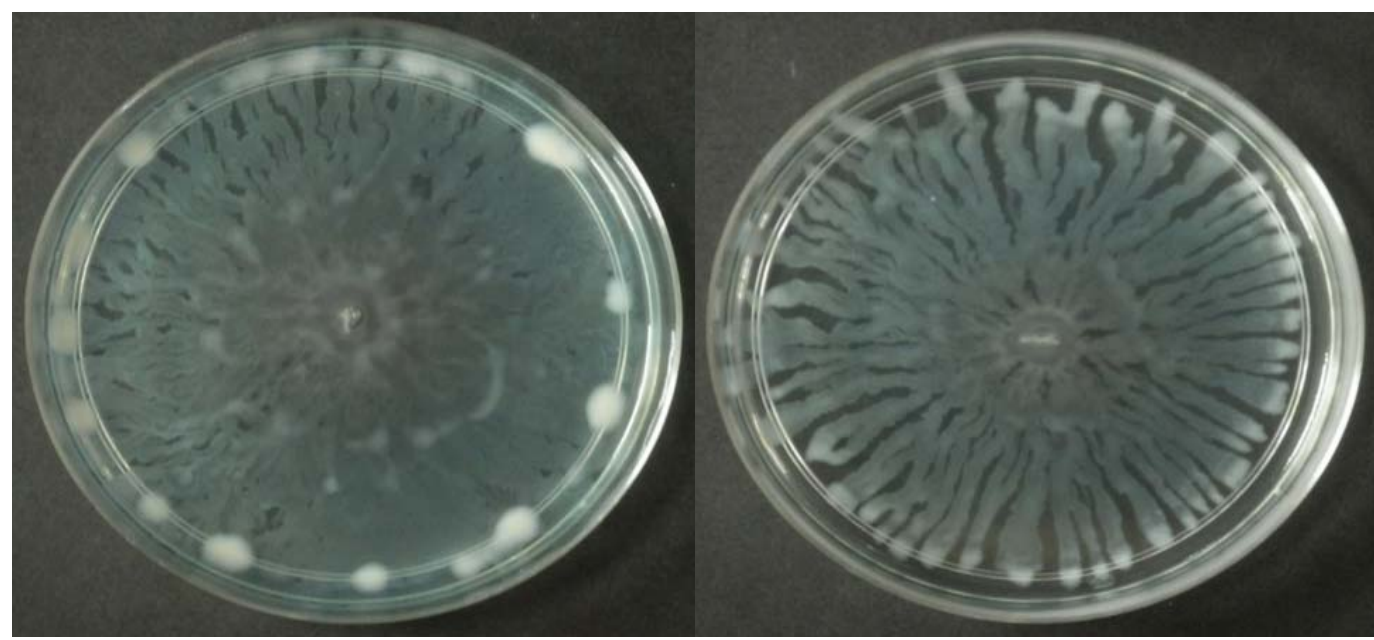

(a)

(b)

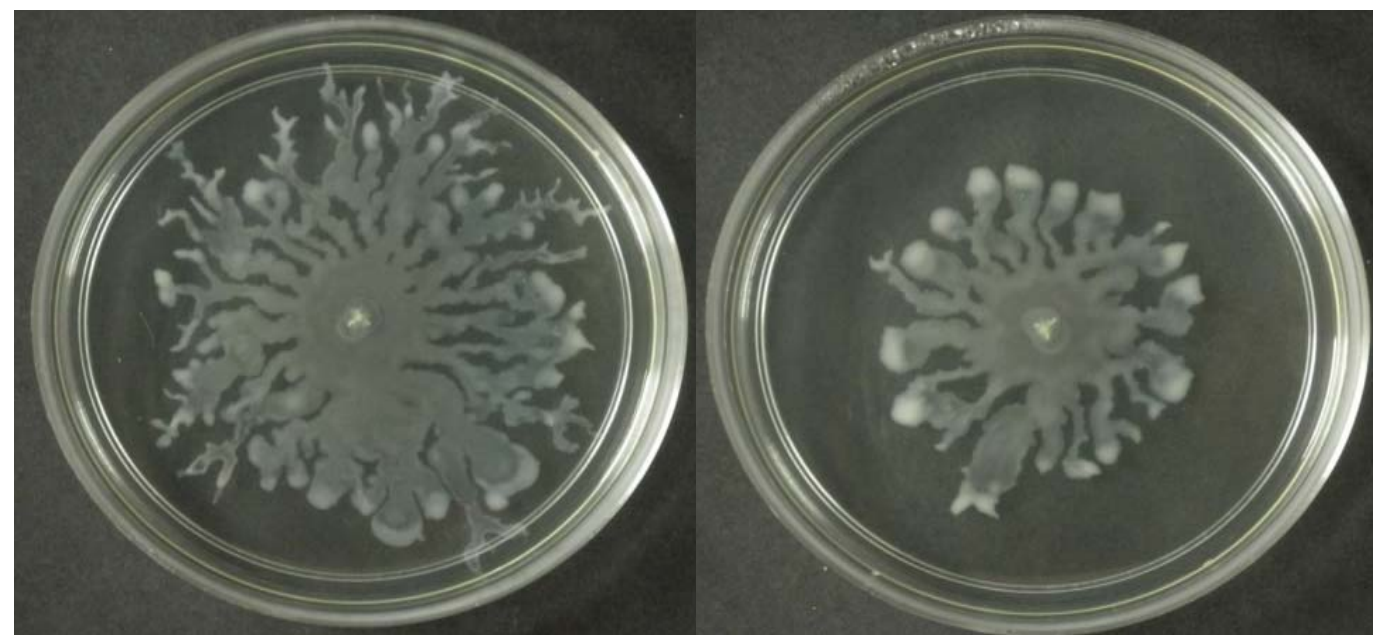

(c)

(d)

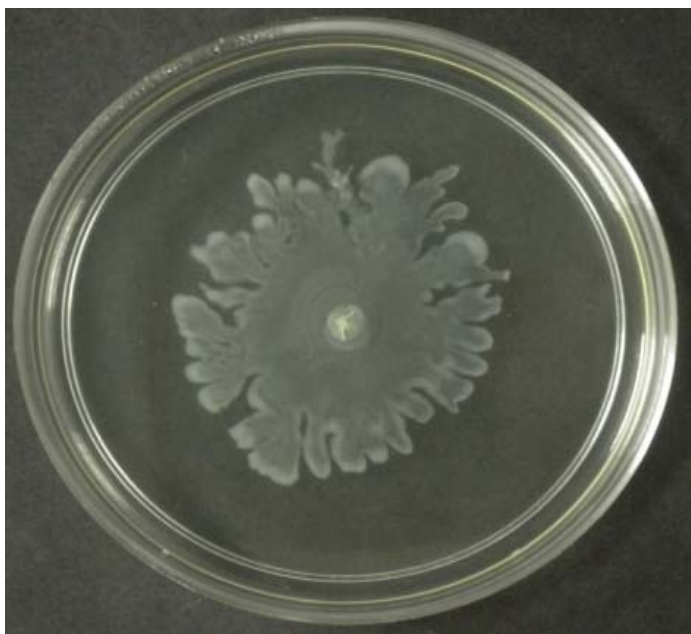

(e) 


\section{Conclusions}

M. lunu-ankenda shows promising anti-QS properties and it has been confirmed that its extracts inhibited QS-dependent virulence determinants of the human pathogens namely P. aeruginosa PAO1. The anti-QS compound from $M$. lunu-ankenda may be a new class of non-bacterial origin antagonist. We are currently in the process of fractionating the $M$. lunu-ankenda extracts by using column chromatography. Identification of the M. lunu-ankenda anti-QS compound is of great interest because it might be possible to overcome the problems posed by emerging antibiotic-resistant bacteria. The promising results obtained from this study prompt us to investigate more Malaysians' endemic plants.

\section{Acknowledgments}

This research was supported by the University of Malaya High Impact Research Grant (UM-MOHE HIR Grant Number A-000001-50001) to Kok-Gan Chan which is gratefully acknowledged.

\section{References}

1. Whitehead, N.A.; Barnard, A.M.L.; Slater, H.; Simpson, N.J.L.; Salmond, G.P.C. Quorum-sensing in Gram-negative bacteria. FEMS Microbiol. Rev. 2001, 25, 365-404.

2. Williams, P.; Camara, M.; Hardman, A.; Swift, S.; Milton, D.; Hope, V.J.; Winzer, K.; Middleton, B.; Pritchard, D.I.; Bycroft, B.W. Quorum sensing and the population-dependent control of virulence. Phil. Trans. Roy. Soc. Lond. 2000, 355, 667-680.

3. Kleerebezem, M.; Quadri, L.E.N.; Kuipers, O.P.; de Vos, W.M. Quorum sensing by peptide pheromones and two-component signal-transduction systems in Gram-positive bacteria. Mol. Microbiol. 1997, 25, 895-904.

4. Visick, K.L.; McFall-Ngai, M.J. An exclusive contract: Specificity in the Vibrio fischeriEuprymna scolopes partnership. J. Bacteriol. 2000, 182, 1779-1787.

5. Storey, D.G.; Ujack, E.E.; Rabin, H.R.; Mitchell, I. Pseudomonas aeruginosa lasR transcription correlates with the transcription of $\operatorname{las} A$, las $B$, and tox $A$ in chronic lung infections associated with cystic fibrosis. Infect. Immun. 1998, 66, 2521-2528.

6. Roger, S.S.; Iglweski, B.H. P. aeruginosa quorum sensing systems and virulence. Curr. Opin. Microbiol. 2003, 6, 56-60.

7. Schuster, M.; Greenberg, E.P. A network of networks: Quorum-sensing gene regulation in Pseudomonas aeruginosa. Int. J. Med. Microbiol. 2006, 296, 73-81.

8. Delden, C.V.; Iglewski, B.H. Cell-to-cell signaling and Pseudomonas aeruginosa infections. Emerg. Infect. Diseases 1998, 4, 551-560.

9. Nicas, T.I.; Iglewski, B.H. The contribution of exoproducts to virulence of Pseudomonas aeruginosa. Can. J. Microbiol. 1985, 66, 43-51.

10. Adonizio, A.L.; Downum, K.; Bennett, B.C.; Mathee, K. Anti-quorum sensing activity of medicinal plants in southern Florida. J. Ethnopharm. 2006, 105, 427-435. 
11. Vandeputte, O.M.; Kiendrebeogo, M.; Rajaonson, S.; Diallo, B.; Mol, A.; Jaziri, M.E.; Baucher, M. Identification of catechin as one of the flavonoids from Combretum albiflorum bark extract that reduces the production of quorum-sensing-controlled virulence factors in Pseudomonas aeruginosa PA01. Appl. Environ. Microbiol. 2010, 76, 243-253.

12. Manefield, M.; de Nys, R.; Kumar, N.; Read, R.; Givskov, M.; Steinberg, P.; Kjelleberg, S. Evidence that halogenated furanones from Delisea pulchra inhibit acylated homoserine lactone (AHL)-mediated gene expression by displacing the AHL signal from its receptor protein. Microbiology 1999, 145, 283-291.

13. Vatte, D.A.; Mihalik, K.; Crixell, S.H.; McLean, R.J.C. Dietary phytochemicals as quorum sensing inhibitors. Fitoterapia 2007, 78, 302-310.

14. Choo, J.H.; Rukayadi, Y.; Hwang, J.-K. Inhibition of bacterial quorum sensing by vanilla extract. Lett. Appl. Microbiol. 2006, 42, 637-641.

15. Lee, C.C.; Houghton, P. Cytotoxicity of plants from Malaysia and Thailand used traditionally to treat cancer. J. Ethnopharm. 2005, 100, 237-243.

16. Chan, E.W.C.; Lim, Y.Y.; Chew, Y.L. Antioxidant activity of Camellia sinensis leaves and tea from a lowland plantation in Malaysia. Food Chem. 2007, 102, 1214-1222.

17. Ali, H.; Houghton, P.J.; Soumyanath, A. $\alpha$-Amylase inhibitory activity of some Malaysian plants used to treat diabetes; with particular reference to Phyllanthus amarus. J. Ethnopharm. 2006, 107, 449-455.

18. McClean, K.H.; Winson, M.K.; Fish, L.; Taylor. A.; Chhabra, S.R.; Camara, M.; Daykin, M.; Lamb, J.H.; Swift, S.; Bycroft, B.W.; Stewart, G.S.A.B.; Williams, P. Quorum sensing and Chromobacterium violaceum: Exploitation of violacein production and inhibition for the detection of $N$-acylhomoserine lactones. Microbiology 1997, 143, 3703-3711.

19. Winzer, K.; Falconer, C.; Garber, N.C.; Diggle, S.P.; Camara, M.; Williams, P. The Pseudomonas aeruginosa lectins PA-IL and PA-IIL are controlled by quorum sensing and by RpoS. J. Bacteriol. 2000, 182, 6401-6411.

20. Winson, M.K.; Swift, S.; Fish, L.; Throup, J.P.; Jorgensen, F.; Chhabra, S.R.; Bycroft, B.W.; Williams, P.; Stewart, G.S.A.B. Construction and analysis of luxCDABE-based plasmid sensors for investigating $\mathrm{N}$-acyl homoserine lactone-mediated quorum sensing. FEMS Microbiol. Lett. 1998, 163, 185-192.

21. Renee, S.B.; Gray, K.M. Extraction of violacein from Chromobacterium violaceum provides a new quantitative bioassay for $N$-acyl homoserine lactone autoinducers. J. Microbiol. Methods 2000, 40, 47-55.

22. Martinelli, D.; Grossmann, G.; Sequin, U.; Brandl, H.; Bachofen, R. Effects of natural and chemically synthesized furanones on quorum sensing in Chromobacterium violaceum. BMC Microbiology 2004, 4, 25.

23. Essar, D.W.; Eberly, L.; Hadero, A.; Crawford, I. Identification and characterization of genes for a second anthranilate synthase in Pseudomonas aeruginosa: Interchangeability of the two anthranilate synthases and evolutionary implications. J. Bacteriol. 1990, 172, 884-900.

24. Bauer, W.D.; Teplitski, M. Can plants manipulate bacterial quorum sensing? Aust. J. Plant Physiol. 2001, 28, 913-921. 
25. Dong, Y.-H.; Xu, J.-L.; Li, X.-Z.; Zhang, L.-H. AiiA, an enzyme that inactivates the acylhomoserine lactone quorum-sensing signal and attenuates the virulence of Erwinia carotovora. Proc. Natl. Acad. Sc. USA 2000, 97, 3526-3531.

26. Leadbetter, J.R.; Greenberg, E.P. Metabolism of acyl-homoserine lactone quorum-sensing signals by Variovorax paradoxus. J. Bacteriol. 2000, 182, 6921-6926.

27. Zhu, H.; Sun, S.J. Inhibition of bacterial quorum sensing-regulated behaviors by Tremella fuciformis extract. Curr. Microbiol. 2008, 57, 418-422.

28. Teplitski, M.; Robinson, J.B.; Bauer, W.D. Plants secrete substances that mimic bacterial $N$-acyl homoserine lactone signal activities and affect population density-dependent behaviors in associated bacteria. Mol Plant-Microbe Interact. 2000, 13, 637-648.

29. Goldberg, J.B.; Pier, G.B. The role of the CFTR in susceptibility to Pseudomonas aeruginosa infections in cystic fibrosis. Trends Microbiol. 2000, 8, 514-520.

30. Lau, G.W.; Hassett, D.J.; Ran, H.; Kong, F. The role of pyocyanin in Pseudomonas aeruginosa infection. Trends Mol. Med. 2004, 10, 599-606.

31. Cao, H.; Krishnan, G.; Goumnerov, B.; Tsongalis, J.; Tompkin, R.S.; Rahme, L.G. A quorum sensing-associated virulence gene of Pseudomonas aeruginosa encodes a LysR-like transcription regulator with a unique self-regulatory mechanism. Proc. Natl. Acad. Sci. USA 2001, 98, 14163-14168.

32. Gallagher, L.A.; McKnight, S.L.; Kuznetsova, M.S.; Pesci, E.C.; Manoil, C. Functions required for extracellular quinolone signaling by Pseudomonas aeruginosa. J. Bacteriol. 2002, 184, 6472-6480.

33. Bjarnsholt, T.; Jensen, P.O.; Rasmussen, T.B.; Christophersen, L.; Calum, H.; Hentzer, M.; Houge, H.-P.; Rygaard, J.; Moser, C.; Eberl, L.; Hoiby, N.; Givskov, M. Garlic blocks quorum sensing and promotes rapid clearing of pulmonary Pseudomonas aeruginosa infections. Microbiology 2005, 151, 3873-3880.

34. Rasmussen, T.B.; Bjarnsholt, T.; Skindersoe, M.E.; Hentzer, M.; Kristoffersen, P.; Kote, M.; Nielsen, J.; Eberl, L.; Givskov, M. Screening for quorum-sensing inhibitors (QSI) by use of a novel genetic system, the QSI selector. J. Bacteriol. 2005, 187, 1799-1814.

35. Avichezer, D.; Katcoff, D.J.; Garber N.C.; Gilboa-Garbar, N. Analysis of the amino-acid sequence of the Pseudomonas aeruginosa galactophilic PA-I lectin. J. Biol. Chem. 1992, 267, 23023-23027.

36. Avichezer, D.; Gilboa-Garber, N.; Garber, N.C.; Katcoff, D. J. Pseudomonas aeruginosa PA-I lectin gene molecular analysis and expression in Escherichia coli. Biochim. Biophys. Acta (BBA) Gene Struct. Expression 1994, 1218, 11-20.

37. Walker, T.S.; Bais, H.P.; Desiel, E.; Schweizer, H.P.; Rahme, L.G.; Fall, R.; Vivanco, J.M. Pseudomonas aeruginosa-plant root interactions. Pathogenicity, biofilm formation, and root exudation. Plant Physiol. 2004, 134, 320-331.

38. Sharma, M.; Anand, S.K. Swarming: A coordinated bacterial activity. Curr. Sci. 2002, 83, 707-715.

39. Kohler, T.; Curty, L.K.; Barja, F.; van Delden, C.; Pechere, J.-D. Swarming of Pseudomonas aeruginosa is dependent on cell-to-cell signaling and requires flagella and pili. J. Bacteriol. 2000, 182, 5990-5996. 
40. Kearns, D.B. A field guide to bacterial swarming motility. Nat. Rev. Microbiol. 2011, 8, 634-644.

41. Eberl, L.; Molin, S.; Givskov, M. Surface motility of Serratia liquefaciens MG1. J. Bacteriol. 1999, 181, 1703-1712.

42. Chong, Y.M.; Yin, W.F.; Ho, C. Y.; Mustafa, M. R.; Hadi, A. H. A.; Awang, K.; Narrima, P.; Koh, K.L.; Appleton, D.R.; Chan, K.G. Malabaricone C from Myristica cinnamomea exhibits anti-quorum sensing activity. J. Nat. Prod. 2011, 74, 2261-2264.

(C) 2012 by the authors; licensee MDPI, Basel, Switzerland. This article is an open access article distributed under the terms and conditions of the Creative Commons Attribution license (http://creativecommons.org/licenses/by/3.0/). 